\title{
Restoration of Parathyroid Responsiveness in Vitamin D-Deficient Rats by Parenteral Calcium or Dietary Lactose *
}

\author{
William Y. W. Au and Lawrence G. Raisz $\ddagger$ \\ (From the Departments of Pharmacology and Medicine, University of Rochester School of \\ Medicine and Dentistry, Rochester, New York)
}

\begin{abstract}
The effects of treatment with vitamin D, calcium, or lactose on the responsiveness of vitamin D-deficient rats to parathyroid hormone were compared. In the absence of vitamin $\mathrm{D}$, parenteral calcium or dietary lactose administration resulted in increases in serum calcium concentration although not to the normal values obtained in animals given vitamin $D$. Dietary lactose also partially restored the low bone calcium content of vitamin D-deficient rats. Untreated vitamin $\mathrm{D}$-deficient rats showed no significant changes in serum calcium concentration after parathyroidectomy or parathyroid extract administration. Vitamin $\mathrm{D}$, lactose, and calcium all restored responsiveness to parathyroid hormone; serum calcium concentration decreased after parathyroidectomy and showed a dose-related increase in response to parathyroid extract. Hence, the unresponsiveness to parathyroid hormone in vitamin $\mathrm{D}$ deficiency may be due to a lack of calcium at a local site of action, presumably bone, rather than to the absence of vitamin $\mathrm{D}$ as a specific cofactor.
\end{abstract}

\section{Introduction}

The observation that hypocalcemia can develop in vitamin D-deficient rats despite parathyroid hyperplasia has led to several studies of the relation between vitamin $\mathrm{D}$ and parathyroid hormone action. Harrison, Harrison, and Park (2) observed that the administration of parathyroid extract (PTE) to vitamin D-deficient, hypocalcemic rats at doses which were effective in normal animals resulted in little or no increase in serum calcium concentration. Rasmussen and coworkers (3)

\footnotetext{
* Received for publication 31 March 1967 and in revised form 15 June 1967.

This study was supported by Grant AM 07871 from the U. S. Public Health Service.

A preliminary report of this work has been published in abstract form (1).

$\ddagger$ Burroughs Wellcome Scholar in Clinical Pharmacology.

Address requests for reprints to Dr. William Y. W. Au, Departments of Pharmacology and Medicine, University of Rochester, School of Medicine and Dentistry, Rochester, N. Y. 14620.
}

confirmed this finding and demonstrated that the already low serum calcium concentration in vitamin D-deficient rats did not decrease further after parathyroidectomy. On the other hand, the usual increase in serum phosphate concentration after parathyroidectomy persisted in these rats. Previously we found that the parathyroid glands of these hypocalcemic, vitamin D-deficient animals were not only enlarged but showed increased function and were able to secrete an active hormone in tissue culture (4). Thus, it appears that the ability of parathyroid hormone (PTH) to increase serum calcium concentration is lost in these rats because the target organ, presumably bone, is unresponsive. Rasmussen and coworkers have suggested that this unresponsiveness is due to the requirement of vitamin $\mathrm{D}$ as a cofactor for calcium transport by parathyroid-stimulated bone cells ( 3 , $5,6)$. This concept was originally based on the finding that mitochondria isolated from vitamin D-deficient animals could respond to parathyroid hormone by accelerated release of calcium only after in vivo restoration of vitamin $D$, In con- 
trast, the stimulation by PTH of mitochondrial phosphate uptake was not vitamin $\mathrm{D}$ dependent. There exists an alternative explanation for parathyroid unresponsiveness. The bones in vitamin $D$ deficiency may have much of their surface covered with unmineralized osteoid. As suggested by Albright and Reifenstein (7), this osteoid tissue could impede movement of calcium from mineralized matrix to body fluid. Thus, if PTH can initiate bone resorption only by translocating calcium (8), when there is little calcium available on the bone surface its action might be blocked. This study was therefore designed to determine whether the treatment of calcium deficiency alone might restore parathyroid responsiveness in vitamin D-deficient animals. When vitamin D-deficient, hypocalcemic animals were not treated, the serum calcium concentration was not altered by parathyroidectomy or PTE administration. Treatment with oral lactose or with parenteral calcium raised the serum calcium concentration and partially restored responsiveness to parathyroid hormone and to parathyroidectomy.

\section{Methods}

Weanling, Holtzman male rats were maintained on a semisynthetic, vitamin $\mathrm{D}$-deficient diet containing $0.4 \%$ calcium and $0.3 \%$ phosphorus under conditions previously described (4). These rats were divided into the following groups: (a) vitamin D-deficient rats $(-\mathrm{D})$; $(b)$ vitamin $\mathrm{D}$-deficient, lactose-fed rats ( $-\mathrm{D} \mathrm{Lac}$ ), given the basic vitamin D-deficient diet except for the substitution of $20 \%$ lactose for an equivalent amount of glucose of the original diet; (c) vitamin D-deficient, calcium-treated rats $(-\mathrm{D} \mathrm{Ca})$, given $1 \mathrm{ml}$ of $0.1 \mathrm{~mm}$ calcium chloride ( $4 \mathrm{mg}$ of $\mathrm{Ca}$ ) by subcutaneous injection every $6 \mathrm{hr}$ for a period of 10 days before the final experimental day (last injection given $15 \mathrm{hr}$ before surgery) ; and (d) vitamin D-treated rats ( $D$ ) given 80 $U$ of vitamin $D$ orally every 3 days. The experiments were carried out after the rats had been on a diet for 4-6 wk.

\section{Experimental procedures}

(a) Parathyroidectomy experiments. Sham operation or parathyroidectomy (PTX) by surgical excision was performed on five or six rats from each of the above experimental groups. Serum calcium and inorganic phosphorus were determined $5 \mathrm{hr}$ later.

(b) Treatment with parathyroid extract (PTE). In one experiment PTE (10 or $40 \mathrm{U} /$ rat) was administered to five rats from each of the $-D,-D$ Lac, or $+\mathrm{D}$ groups at the time of parathyroidectomy. Serum calcium and phosphorus concentrations were measured in blood obtained by heart puncture $5 \mathrm{hr}$ after parathyroidectomy and compared with values obtained from control rats given a solution of $0.9 \%$ sodium chloride with $1.6 \%$ glycerol and $0.2 \%$ phenol. In other experiments groups of five to seven $-\mathrm{D},-\mathrm{D}$ Lac, $-\mathrm{D} \mathrm{Ca}$, or $+\mathrm{D}$ rats were given PTE in various doses (see Results) subcutaneously $5 \mathrm{hr}$ after surgical parathyroidectomy. Serum calcium and phosphorus concentrations were determined in blood obtained by orbital sinus puncture immediately preceding and $5 \mathrm{hr}$ after PTE injection (5 and $10 \mathrm{hr}$ after PTX). Sham-operated or parathyroidectomized rats were injected with control saline, phenol, and glycerol solution. Surgical procedures and blood sampling were done under ether anesthesia.

Chemical analysis. Serum calcium and inorganic phosphorus concentrations were estimated by previously described methods (9). Determinations of bone ash and calcium content were based on the method of Mulryan, Neuman, Neuman, and Toribara (10). To determine whether the effects of lactose might be due to contamination with vitamin $\mathrm{D}$, we extracted with dichloromethane $100-200-g$ aliquots of lactose used in the vitamin D-deficient, lactose diet. This lipid extract was dried under nitrogen and examined for the presence of vitamin D either by chemical analysis ${ }^{1}$ or by bioassay. For bioassay, dried lipid extract was dissolved in sesame oil and administered orally to hypocalcemic, vitamin D-deficient rats. Each rat received a dose which represented an extract of the amount of lactose fed in 7 days on the vitamin $\mathrm{D}$-deficient, lactose diet. The effect on serum calcium concentration 3 and 7 days after administration of the extract was compared with that of animals given small doses of vitamin $\mathrm{D}$ or control animals given only sesame oil.

The data are presented as the mean $\pm \mathrm{SE}$ and as significance of differences between groups by Student's $t$ test.

\section{Results}

Rats on the vitamin D-deficient diet did not grow as well as animals treated with vitamin D and developed marked hypocalcemia with a normal serum phosphorus concentration. These changes were regarded by Steenbock and Herting (12) as criteria for vitamin D deficiency for rats on similar diets. Lactose-fed, vitamin D-deficient rats maintained normal serum calcium concentrations but did not grow as well as vitamin D-treated rats (Table I). The mean body weight for all lactosefed, vitamin D-deficient rats $(n=32)$ was $161 \pm$ $2.5 \mathrm{~g}$ and this was significantly greater than the mean value for untreated, vitamin D-deficient rats $(\mathrm{n}=25)$ of $151 \pm 3.8 \mathrm{~g}(P<.0 .05)$. Parenteral calcium treatment of vitamin D-deficient rats for

1 Chemical assays for vitamin D were kindly carried out by Dr. Philip S. Chen who used the method developed in his laboratory (11). 
TABLE I

Body weight and changes in serum calcium $(C a)$ and phosphorus $(P)$ concentrations of vitamin D-deficient $(-D)$ rats treated with lactose $(-D$ Lac), parenteral calcium $(-D C a)$, or vitamin $D(+D)$ $5 \mathrm{hr}$ after sham operation (Sham) or parathyroidectomy (PTX)

\begin{tabular}{|c|c|c|c|c|c|c|c|c|}
\hline \multirow[b]{2}{*}{ Group } & \multicolumn{4}{|c|}{ Sham } & \multicolumn{4}{|c|}{ PTX } \\
\hline & $\mathrm{n}$ & Body wt & $\mathrm{Ca}$ & $P$ & $\mathrm{n}$ & Body wt & $\mathrm{Ca}$ & $P$ \\
\hline & & $g$ & $m g /$ & $\mathrm{ml}$ & & $g$ & $m g /$ & $m l$ \\
\hline $\begin{array}{l}\text {-D } \\
-\mathrm{D} \mathrm{Lac} \\
-\mathrm{D} \mathrm{Ca} \\
+\mathrm{D}\end{array}$ & $\begin{array}{r}11 \\
6 \\
5 \\
11\end{array}$ & $\begin{array}{l}152 \pm 6 \\
166 \pm 4 \\
157 \pm 10 \\
208 \pm 4 \ddagger\end{array}$ & $\begin{array}{l}4.5 \pm 0.2 \\
8.9 \pm 0.2 \ddagger \\
6.9 \pm 0.2 \ddagger \\
9.1 \pm 0.1 \ddagger\end{array}$ & $\begin{array}{l}8.9 \pm 0.5 \\
7.1 \pm 0.3 \\
6.3 \pm 0.3 \ddagger \\
8.4 \pm 0.3\end{array}$ & $\begin{array}{l}17 \\
23 \\
15 \\
37\end{array}$ & $\begin{array}{l}154 \pm 3 \\
160 \pm 3 \\
154 \pm 3 \\
212 \pm 3\end{array}$ & $\begin{array}{l}4.4 \pm 0.2 \\
7.9 \pm 0.1^{*} \\
5.0 \pm 0.1^{*} \\
8.3 \pm 0.1^{*}\end{array}$ & $\begin{array}{c}14.4 \pm 1.0 \\
7.2 \pm 0.2 \\
7.0 \pm 0.4 \\
9.4 \pm 0.2^{*}\end{array}$ \\
\hline
\end{tabular}

Values are mean $\pm \mathrm{sE}$. All rats were maintained on vitamin $\mathrm{D}$-deficient diet, Ca: $P=0.4 / 0.3$ for 6 wk. $-\mathrm{D}$ Lac rats received $20 \%$ lactose substituted for equivalent amount of glucose in the basic diet; $-\mathrm{D} C \mathrm{Ca}$ rats received $1 \mathrm{ml}$ of $0.1 \mathrm{~mm}$ calcium $\left(\mathrm{CaCl}_{2}\right)$ s.c. every $6 \mathrm{hr}$ for 10 days before sacrifice; $+\mathrm{D}$ rats received $80 \mathrm{U}$ of vitamin $\mathrm{D}$ orally every 3 days.

* Significant difference between PTX and sham-operated group, $P<0.01$.

$\ddagger$ Significant difference from $-\mathrm{D}$ group, $P<0.01$, (sham-operated animals only).

10 days increased serum calcium and decreased serum phosphorus concentrations significantly but did not alter body weight (Table I).

Changes in bone ash and calcium content for two experiments are shown in Table II. In both experiments vitamin $\mathrm{D}$-deficient rats had lower bone ash and calcium contents as percentages of dry weight than did the treated animals. Lactose feeding caused a slight increase in ash and calcium contents but did not restore the values to those of the vitamin $\mathrm{D}$-treated rats. The shorter treatmen with parenteral calcium did not increase calcium or ash contents significantly; the mean values were only about $2 \%$ higher than those for untreated, vitamin $\mathrm{D}$-deficient rats.

Effects of parathyroidectomy. The already low serum calcium concentration in vitamin D-deficient rats did not fall further after parathyroidectomy but serum phosphorus concentration increased markedly, confirming the previous results of Rasmussen and coworkers (3) (Table I). All three treated groups, lactose, parenteral calcium, and vitamin $\mathrm{D}$, responded to parathyroidectomy with a small but significant decrease in serum calcium concentration and little change in the serum phosphorus concentration. The decrease in serum calcium concentration was less than that usually observed in animals maintained on a low calcium diet as in the Munson assay for parathyroid hormone (13) and may reflect the greater availability of dietary calcium during the $5 \mathrm{hr}$ period after parathyroidectomy. The experiments also differed from the Munson assay in that surgical removal rather than cautery was used, so that thyrocalcitonin release was kept minimal.

Response to parathyroid extract. Parathyroid responsiveness was assayed in two ways. 1) The standard Munson assay technique in which PTE is administered at the time of parathyroidectomy and its ability to maintain serum calcium concen-

TABLE II

Bone ash and calcium percentages for vitamin $D$-deficient rats treated with dietary lactose ( $-D$ Lac), parenteral calcium $(-D C a)$, or vitamin $D(+D)$

\begin{tabular}{|c|c|c|c|c|}
\hline \multirow[b]{2}{*}{ Experiment } & \multirow[b]{2}{*}{ Treatment } & \multirow[b]{2}{*}{$\mathbf{n}$} & \multicolumn{2}{|c|}{ Per cent of fat-free dry weight } \\
\hline & & & Ash & Calcium \\
\hline 249 & $\begin{array}{l}-\mathrm{D} \\
-\mathrm{D} \text { Lac } \\
+\mathrm{D}\end{array}$ & $\begin{array}{l}5 \\
5 \\
5\end{array}$ & $\begin{array}{l}55.5 \pm 0.5 \\
56.9 \pm 0.7 \\
58.9 \pm 0.6 \ddagger\end{array}$ & $\begin{array}{l}19.4 \pm 0.4 \\
21.0 \pm 0.4^{*} \\
22.7 \pm 0.2 \ddagger\end{array}$ \\
\hline 420 & $\begin{array}{l}-\mathrm{D} \\
-\mathrm{D} C \mathrm{Ca} \\
+\mathrm{D}\end{array}$ & $\begin{array}{l}7 \\
7 \\
7\end{array}$ & $\begin{array}{l}52.2 \pm 0.7 \\
52.9 \pm 0.7 \\
59.7 \pm 0.6 \ddagger\end{array}$ & $\begin{array}{l}17.5 \pm 0.4 \\
17.9 \pm 0.5 \\
21.1 \pm 1.0 \ddagger\end{array}$ \\
\hline
\end{tabular}

Values are mean $\pm \mathrm{SE}$.

* Significant difference from $-\mathrm{D}$ values of each experiment, $P<0.05$.

$\ddagger$ Significant difference from $-\mathrm{D}$ values of each experiment, $P<0.01$. 
TABLE III

Effect of parathyroid extract (PTE) on serum calcium $(C a)$ and phosphorus $(P)$ concentrations of vitamin $D$-deficient $(-D)$, lactose-fed $(-D$ Lac), and vitamin $D$-treated $(+D)$ rats

\begin{tabular}{|c|c|c|c|c|c|c|}
\hline \multirow{2}{*}{$\underset{\text { U/rat }}{\text { Dose PTE }}$} & \multicolumn{2}{|c|}{$-D$} & \multicolumn{2}{|c|}{-D Lac } & \multicolumn{2}{|c|}{$+\mathrm{D}$} \\
\hline & $\mathrm{Ca}$ & $P$ & $\mathrm{Ca}$ & $P$ & $\mathrm{Ca}$ & $\mathbf{P}$ \\
\hline 0 & $4.6 \pm 0.3$ & $19.3 \pm 0.4$ & $8.1 \pm 0.2$ & $9.9 \pm 0.2$ & $8.2 \pm 0.5$ & $10.8 \pm 0.4$ \\
\hline 10 & $4.8 \pm 0.7$ & $13.9 \pm 2.1^{*}$ & $9.1 \pm 0.2^{*}$ & $10.8 \pm 1.0$ & $10.0 \pm 0.3^{*}$ & $9.9 \pm 0.3$ \\
\hline 40 & $4.1 \pm 0.6$ & $12.5 \pm 0.7 \ddagger$ & $9.9 \pm 0.3 \ddagger$ & $8.9 \pm 0.4$ & $10.4 \pm 0.5^{*}$ & $7.9 \pm 0.2 \ddagger$ \\
\hline
\end{tabular}

Values are mean $\pm \mathrm{SE}, \mathrm{mg} / 100 \mathrm{ml}, 5 \mathrm{hr}$ after parathyroidectomy for groups of 3 to 5 rats. PTE given subcutaneously at time of parathyroidectomy. 0 PTE rats given $0.9 \%$ saline with $1.6 \%$ glycerol and $0.2 \%$ phenol solution.

* Significant difference from 0 PTE values, $P<0.05$.

‡ Significant difference from 0 PTE values, $P<0.01$.

tration $5 \mathrm{hr}$ later is determined. Table III shows the results of such an assay for doses of 10 or $40 \mathrm{U}$ of PTE per rat. Both lactose-treated and vitamin D-treated animals showed a significant response, whereas vitamin D-deficient animals did not show a response in serum calcium concentration but did show a decrease in phosphorus concentration. Vitamin D-treated rats also showed a decrease in serum phosphorus concentration at the higher dose level of PTE. 2) To be certain (a) that the animals were successfully parathyroidectomized before PTE administration, (b) that high circulating levels of endogenous parathyroid hormone would have disappeared, ${ }^{2}$ and also $(c)$ that differences in body weight among the treatment groups are taken into account, we performed another series of PTE assays in the following manner. Blood samples were taken $5 \mathrm{hr}$ after parathyroidectomy and PTE was given in doses based on body weight. Blood samples were taken again $5 \mathrm{hr}$ later. Animals which did not show a significant fall in serum calcium concentration after parathyroidectomy were discarded. As seen in Fig. 1, the responses to doses of 5,20 , or $80 \mathrm{U}$ of PTE per $100 \mathrm{~g}$ of body weight in lactose-treated and in vitamin D-treated rats were quite similar. In contrast, doses of $80 \mathrm{U}$ or even $160 \mathrm{U}$ of PTE per $100 \mathrm{~g}$ of body weight had no effect on serum calcium concentration in the vitamin D-deficient animals. The response in rats treated with parenteral calcium was intermediate. Serum calcium concentrations before and after parathyroidectomy were lower than those for lactose-treated or vitamin D-treated animals;

2 The half-life of PTH has been estimated in normal -rats at less than $30 \mathrm{~min}$ (14). Unless the half-life were markedly prolonged in vitamin D deficiency, there should have been negligible amounts of circulating $\mathrm{PTH}$ after $5 \mathrm{hr}$. and, whereas there was no significant response to $5 \mathrm{U}$ of PTE per $100 \mathrm{~g}$ of body weight, a dose of $80 \mathrm{U}$ increased serum calcium concentration by 2 $\mathrm{mg} / 100 \mathrm{ml}$.

Assay for vitamin $D$ activity in lactose. To exclude the possibility that the serum calcium concentration was increased because there was vitamin $\mathrm{D}$ contamination of the lactose used in the diets, we chemically and biologically assayed lipid extracts of aliquots of the same lot of lactose. The

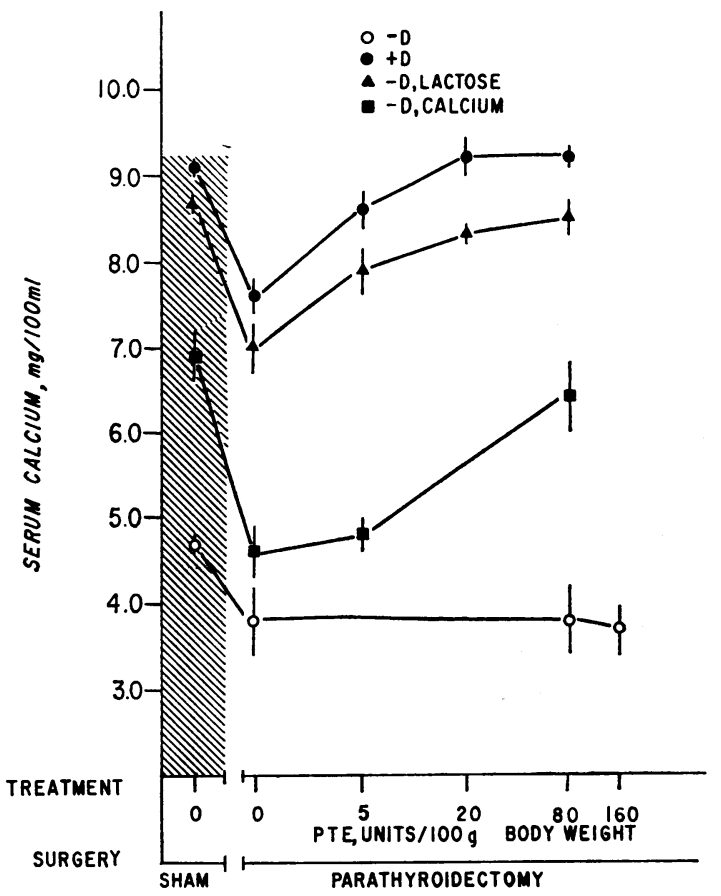

Fig. 1. Serum calcium concentration responses to PARATHYROID EXTRACT (PTE) IN VITAMIN D-DEFICIENT RATS TREATED WITH LACTOSE, PARENTERAL CALCIUM, OR viTAMIN D. Serum calcium determined $5 \mathrm{hr}$ after various doses of PTE were administered to parathyroidectomized rats (see text). Values are mean $\pm \mathrm{SE}$ for groups of 5-11 rats. 
TABLE IV

Effect of lactose extract or vitamin $D$ treatment on serum calcium concentration of vitamin $D$-deficient rats

\begin{tabular}{|c|c|c|c|}
\hline \multirow[b]{2}{*}{ Treatment } & \multirow[b]{2}{*}{$\mathrm{n}$} & \multicolumn{2}{|c|}{ Serum calcium concentration } \\
\hline & & Day 2* & Day 7* \\
\hline & & \multicolumn{2}{|c|}{$m g / 100 m l$} \\
\hline Sesame oil & 12 & $4.9 \pm 0.2$ & $4.8 \pm 0.2$ \\
\hline Lactose extract & 11 & $4.5 \pm 0.1$ & $4.4 \pm 0.1$ \\
\hline Vitamin $\mathrm{D}, 2 \mathrm{U}$ & 9 & $5.9 \pm 0.1 \ddagger$ & $6.7 \pm 0.3 \ddagger$ \\
\hline Vitamin $\mathrm{D}, 5 \mathrm{U}$ & 4 & $6.1 \pm 0.4 \ddagger$ & $7.3 \pm 0.4 \ddagger$ \\
\hline Lactose $+\mathrm{D}$ extract & 5 & $6.3 \pm 0.2 \ddagger$ & $7.2 \pm 0.4 \ddagger$ \\
\hline
\end{tabular}

* 2 and 7 days after single oral dose of treatment material given to rats maintained on vitamin $\mathrm{D}$-deficient diet, Ca : $\mathrm{P}=0.4 / 0.3$. Lactose extract is dichloromethaneextracted material from an amount of lactose equivalent to 7 days' oral feeding per rat. Lactose $+D$ extract is same amount of material similarly extracted from lactose with added vitamin D estimated to supply a preextraction dose of $5 \mathrm{U}$ per rat.

$\ddagger$ Significant difference from sesame oil control value for the corresponding day, $P<0.01$.

chemical assay method could detect $0.1-1 \mu \mathrm{g}$ or 4-40 U of vitamin D on the final thin layer chromatograms. In two separate experiments an extract of the amount of lactose equivalent to 5 days intake for one rat showed no visible spot. Nevertheless, the sensitivity of vitamin D-deficient animals to vitamin $\mathrm{D}$ is so great that this did not rule out the possibility of biological activity in the extracts. Therefore, vitamin D-deficient rats were given the extract prepared from an amount of lactose equivalent to 7 days' intake and the response was compared to that obtained with small amounts of vitamin D (Table IV). Feeding of this amount of lactose had previously been found to raise the serum calcium concentration of vitamin D-deficient rats (4). The ability to recover added vitamin $\mathrm{D}$ by this extraction procedure was also tested. As shown in Table IV, lactose extract had no effect on serum calcium concentration while 2 $U$ of vitamin D increased serum calcium significantly and $5 \mathrm{U}$ had the same effect whether given directly or added to lactose and recovered in the lipid extract.

\section{Discussion}

Although the observation that vitamin D-deficient animals may be unresponsive to parathyroid hormone has been made by a number of workers $(2,3,15)$ there are conflicting reports indicating that parathyroid hormone and parathyroidectomy have appropriate effects in vitamin $\mathrm{D}$-deficient rats
(16), mice (17), and dogs (18). A possible objection has been that there may be trace amounts of vitamin $\mathrm{D}$ remaining in the responsive animals. In our studies parathyroid hormone-unresponsive hypocalcemia was demonstrated and responsiveness could be restored by repeated injections of calcium chloride, or by administering dietary lactose which presumably increased calcium absorption (19). Although the mechanism whereby dietary lactose improves calcium absorption in D-deficient animals is not known, Lengemann, Wasserman, and Comar (20) have shown a rapid direct effect of lactose on ${ }^{45} \mathrm{Ca}$ and ${ }^{89} \mathrm{Sr}$ transport by isolated intestinal segments in rachitic rats, an effect which is not obtained by direct addition of vitamin $\mathrm{D}$. In our own study, the possibility that lactose could act because of contamination with vitamin $\mathrm{D}$ was ruled out by assay of the lactose used in the diets. The restoration of parathyroid responsiveness with lactose feeding is not necessarily due to a restoration of responsiveness of bone to the hormone, since it is possible that lactose would increase the sensitivity of the gut to the effects of parathyroid hormone. Hence PTE would stimulate absorption of calcium and parathyroidectomy would decrease absorption, resulting in the observed changes in serum calcium concentration. For this reason, the ability to restore parathyroid hormone responsiveness with parenteral injections of calcium alone was tested. These injections were maintained for only 10 days and though the restoration of parathyroid hormone responsiveness was incomplete, the results nevertheless indicate that an increase in the amount of calcium available in tissue, probably bone, was the major determinant of the ability of parathyroid hormone to raise serum calcium concentration. Bone ash and calcium content in lactose-fed rats were slightly higher than those in vitamin D-deficient rats, but those in calcium-injected rats were not significantly different. A relatively small amount of calcium was injected and this calcium was not given with phosphorus so that its deposition in bone may have been limited. If only a small amount of the administered calcium was retained, it is likely that this would be deposited at the surface of bone in areas of poorly mineralized osteoid. Engfeldt, Hjertquist, Solheim, and Vejlens (21) have recently demonstrated improved mineralization of bone by repeated calcium injec- 
tions in rachitic dogs. In contrast to our findings after parenteral calcium administration, Arnaud and coworkers (6) were able to produce a normal serum calcium concentration with a high calcium diet in vitamin D-deficient rats but unresponsiveness to parathyroidectomy and to parathyroid hormone persisted. One possible explanation is that there was insufficient phosphate for mineralization with high dietary calcium: phosphorus ratios in these animals. Several investigators $(22,23)$ have shown that such diets result in classical rickets and severe deficiencies in bone mineralization with marked decreases of bone ash content. The data from our own laboratory corroborate these findings, since the percentage of calcium in fatfree dried tibia and the serum calcium concentration in vitamin $\mathrm{D}$-deficient animals given the same semisynthetic diet but with a high calcium intake (Ca: $\mathrm{P}$ ratio of 8 ) was only $13.9 \%$ with a serum calcium concentration of $9.5 \mathrm{mg} / 100 \mathrm{ml}$ compared to values of $18.6 \%$ for bone calcium and $10.7 \mathrm{mg} /$ $100 \mathrm{ml}$ for serum calcium concentration in vitamin D-treated animals on the same diet (unpublished observations).

The results of the present study can be explained if the relation between vitamin D and parathyroid hormone is based on availability of calcium and not on any direct participation of vitamin $\mathrm{D}$ as a cofactor for parathyroid hormone action. Data obtained in tissue culture (8) suggest that parathyroid hormone first initiates a movement of calcium from bone to the bathing medium. Subsequently there is stimulation of RNA synthesis and cell transformation resulting in osteoclastic resorption of matrix and further calcium release. A somewhat similar initial calcium translocation step for vitamin $\mathrm{D}$ action in the gut was proposed by Zull, Czarnowska-Misztal, and DeLuca (24). In vitamin $\mathrm{D}$-deficient animals mineralization is deficient, and the surface of the bone may gradually become covered with poorly mineralized osteoid. Whether it is the lack of calcium in this osteoid tissue or in the adjacent bone cells which is the significant factor limiting parathyroid hormone action is not known. In any case, the primary action of vitamin $\mathrm{D}$ in restoring parathyroid responsiveness would be its increase of intestinal calcium absorption and restoration of critical calcium concentration in the sites for hormone action. The action of oral lactose would be entirely similar, while parenteral calcium would restore the critical concentration more directly.

\section{Acknowledgment}

We thank Mrs. Judith R. Engerman for her skillful technical assistance.

\section{References}

1. Au, W. Y. W., J. R. Engerman, and L. G. Raisz. 1966. Effect of dietary lactose on parathyroid hormone activity in vitamin $\mathrm{D}$ deficient rats. Clin. Res. $14: 277$. (Abstr.)

2. Harrison, H. C., H. E. Harrison, and E. A. Park. 1958. Vitamin D and citrate metabolism: effect of vitamin $\mathrm{D}$ in rats fed diets adequate in both calcium and phosphorus. Am. J. Physiol. 192 : 432.

3. Rasmussen, H., H. DeLuca, C. Arnaud, C. Hawker, and M. von Stedingk. 1963. The relationship between vitamin $\mathrm{D}$ and parathyroid hormone. $J$. Clin. Invest. 42 : 1940.

4. Au, W. Y. W., and L. G. Raisz. 1965. Effect of vitamin $\mathrm{D}$ and dietary calcium on parathyroid activity. Am. J. Physiol. 209: 637.

5. DeLuca, H. F., G. W. Engstrom, and H. Rasmussen. 1962. The action of vitamin D and parathyroid hormone in vitro on calcium uptake and release by kidney mitochondria. Proc. Natl. Acad. Sci. U. S. 48: 1604.

6. Arnaud, C., H. Rasmussen, and C. Anast. 1966. Further studies on the interrelationship between parathyroid hormone and vitamin D. J. Clin. Invest. $45: 1955$.

7. Albright, F., and E. C. Reifenstein, Jr. 1948. The Parathyroid Glands and Metabolic Bone Disease. Williams \& Wilkins Co., Baltimore. 206.

8. Raisz, L. G., and I. Niemann. 1967. Early effects of parathyroid hormone and thyrocalcitonin on bone in organ culture. Nature. 214: 486.

9. Raisz, L. G. 1965. Bone resorption in tissue culture. Factors influencing the response to parathyroid hormone. J. Clin. Invest. 44: 103.

10. Mulryan, B. J., M. W. Neuman, W. F. Neuman, and T. Y. Toribara. 1964. Equilibration between tissue calcium and injected radiocalcium in the rat. Am. J. Physiol. 207 : 947.

11. Chen, P. S., Jr., A. R. Terepka, K. Lane, and A. Marsh. 1965. Studies of the stability and extractability of vitamin D. Anal. Biochem. 10: 421.

12. Steenbock, H., and D. C. Herting. 1955. Vitamin D and growth. J. Nutr. $57: 449$.

13. Munson, P. L. 1961. Biological assay of parathyroids. In The Parathyroids; Proceedings of the Symposium on Advances in Parathyroid Research. R. O. Greep and R. V. Talmage, editors. Charles C Thomas, Springfield. 94.

14. Melick, R. A., G. D. Aurbach, and J. T. Potts, Jr. 1965. Distribution and half life of ${ }^{181} \mathrm{I}$ labeled 
parathyroid hormone in the rat. Endocrinology. $77: 198$.

15. Marnay, C., and T. Raoul. 1959. Role indispensable de la vitamine $\mathrm{D}$ pour observer l'action hypercalcemeante de l'homme parathyroidienne chez le rat normal. Compt. Rend. Soc. Biol 153: 1949.

16. Toverud, S. U. 1964. The effect of parathyroid hormone and vitamin $\mathrm{D}$ on serum calcium in rats. Acta Physiol. Scand. 62: 391.

17. Nichols, G., Jr., S. Schartum, and G. M. Vaes. 1963. Some effects of vitamin D and parathyroid hormone on the calcium and phosphorus metabolism of bone in vitro. Acta Physiol. Scand. 57: 51.

18. Ney, R. L., W. Y. W. Au, G. Kelly, I. Radde, and F. C. Bartter. 1965. Actions of parathyroid hormone in the vitamin D-deficient dog. J. Clin. Invest. 44 : 2003.

19. Dupuis, Y., and P. Fournier. 1963. Lactose and the absorption of calcium and strontium. In The Transfer of Calcium and Strontium Across Biological Membranes. R. H. Wasserman, editor. Academic Press Inc., New York. 277.
20. Lengemann, F. W., R. H. Wasserman, and C. L. Comar. 1959. Studies on the enhancement of radiocalcium and radiostrontium absorption by lactose in the rat. J. Nutr. $68: 443$.

21. Engfeldt, B., S. O. Hjertquist, K. Solheim, and L. Vejlens. 1966. The effect of calcium and phosphate administration on mineralizing tissue in rachitic dogs; A histologic, microradiographic, chemical study. Acta Soc. Med. Upsalien. 71: 41.

22. Brown, H. B., A. T. Shohl, E. E. Chapman, C. S. Rose, and E. M. Saurwein. 1932. Rickets in rats. XIII. The effect of various levels and ratios of calcium to phosphorus in the diet upon the production of rickets. J. Biol. Chem. 98: 207.

23. Bethke, R. M., C. H. Kick, and W. Wilder. 1932. The effect of the calcium-phosphorus relationship on growth, calcification, and blood composition of the rat. J. Biol. Chem. 98: 389.

24. Zull, J. E., E. Czarnowska-Misztal, and H. F. DeLuca. 1966. On the relationship between vitamin $\mathrm{D}$ action and actinomycin-sensitive processes. Proc. Natl. Acad. Sci. U. S. 55 : 177. 